\title{
Empirical Analysis of the Impact of Foreign Exchange Reserves to Economic Growth in Emerging Economics
}

\author{
Borivoje D. Krušković ${ }^{1} \&$ Tina Maričić ${ }^{1}$ \\ ${ }^{1}$ Faculty of Economics, University of Banja Luka, Bosnia \& Herzegovina, Europe \\ Correspondence: Borivoje D. Krušković, Faculty of Economics, University of Banja Luka, Bosnia \& Herzegovina, \\ Europe.
}

Received: December 12, 2014

Accepted: December 29, 2014

Available online: January 27, 2015

doi:10.11114/aef.v2i1.653

URL: http://dx.doi.org/10.11114/aef.v2i1.653

\begin{abstract}
In this paper we analyzed the effect of the accumulation of foreign exchange reserves to economic growth in emerging countries. In order to empirical estimates of the impact of foreign exchange reserves to economic growth in emerging countries, were collected annual data on real GDP per capita, share of investment in GDP and population from the database of the International Monetary Fund (IMF WEO) in October 2013, while data from the level of foreign exchange reserves statistics collected from the relevant central banks. For a balanced panel data for Brazil, China and Russia, for the period from 1993 to 2012, estimated the relationship between economic growth and changes in foreign exchange reserves by applying the method includes the ONK with fixed individual effects. The empirical results in this paper suggest that the increase in foreign exchange reserves causes the growth of GDP, while in the opposite direction causality has not been proven. Exchange rate depreciation that occurs as a result of the accumulation of foreign exchange reserves is not inflationary because it is a one-time, non-persistent shock, unlike the sudden depreciation of the exchange rate that occurs as a result of maintaining an overvalued exchange rate in the long term and leads to currency crisis. The accumulation of foreign exchange reserves does not lead to inflation if the rate of accumulation of foreign exchange reserves does not exceed the rate of economic growth. Slightly higher inflation is not necessarily harmful, particularly for developing economics and emerging economics.
\end{abstract}

Keywords: foreign exchange reserves, economic growth, monetary policy

JEL: E52, E58, F31.

\section{Introduction}

Emerging economics (Brazil, Russia, China, Argentina, Singapore, South Africa, India, etc.) at the beginning of the nineties significantly increased foreign exchange reserves. The trend of increasing foreign exchange reserves began around 1990, which marks the beginning of the era of financial globalization. Due to the potential impact on global interest rates, economic growth and financial stability, it is essential to the accumulation of foreign exchange reserves in these countries. The rapid increase in the level of foreign exchange reserves in recent years has focused only on the security of any foreign exchange crisis, but also a tendency of policy makers to prevent the appreciation of the exchange rate and maintain the competitiveness of their economies. It is possible to find an analogy between the accumulation of foreign exchange reserves and the Keynesian policy of fiscal expansion that running the country out of recession. When the government engages in a recession unemployed for any type of business, real GDP is approaching potential level. Similarly, under certain conditions, the central bank can stimulate economic growth undervalued exchange rate through the accumulation of foreign exchange reserves. An important difference compared to the standard Keynesian effect is that here talking about long-term growth rate of GDP, not the deviation of the real relative to potential GDP. Strong economic growth follows the accumulation of foreign exchange reserves in order to create resilience to external shocks.

The accumulation of foreign exchange reserves in emerging economics is analogous to the increase in the current account deficit in countries whose currency is used for accumulation, especially in the United States. As a result, adjustments in the United States have significant costs for the rest of the world, especially in countries which accumulate foreign exchange reserves in dollars. The experience of emerging countries shows the importance of the accumulation of foreign exchange reserves in order to solve unforeseen situations, volatile capital flows and other developments that may adversely affect expectations. 
Excessive consumption in the USA forced the countries of East Asia to achieve a surplus in the current account and accumulate dollar foreign exchange reserves to avoid the appreciation of the exchange rate and deflation. China still recorded a huge trade surplus and the US continue to spend and borrow, thus putting themselves and the rest of the world into a new danger, with unforeseeable consequences. It is understood that the central bank is trying to have a bigger stock of foreign exchange reserves to defend the exchange rate from possible future shocks. Asian central banks are trying to maintain undervalued exchange rate and high demand for exports. Such a policy to competitiveness in the world market and foreign direct investment.

Although the foreign exchange reserves of industrialized countries have increased, the increases were not matched with an increase in foreign exchange turnover or total financial flows. Thus, in relative terms, the foreign exchange reserves of industrialized countries decreased. Despite the high level of global foreign exchange reserves, increasing foreign exchange reserves will probably continue. As they increased international transactions in terms of globalization and internationalization, will require a higher level of foreign exchange reserves. Countries with a strong currency (US dollar or pound sterling) do not accumulate significant levels of foreign exchange reserves since those currencies acceptable worldwide. Also, in the case of strong currencies, the exchange rate is less dependent on the level of foreign exchange reserves, and more than the level of development of the economy. In this case, the exchange rate appreciates or depreciates rarely based on how the foreign exchange reserves accumulated by the central bank, but rather on the basis of corporate indicators, economic parameters and capital market developments.

The increasing liquidity in other strong currencies, a growing current account deficit and external debt of the United States have increased the pressure on central banks to diversify their foreign exchange reserves. Great twist portfolio will significantly affect the exchange rates and the status of the dollar as the dominant international currency. The fall in the value of the US dollar will occur in the near future. The status of the dollar as the world's only reserve currency at the moment will change. In the future we should expect a diminishing role of the dollar and the creation of more reserve currency of the world. In the long run, the world will move toward several areas of new major world currencies and the dollar will lose the monopoly that is now in the global financial system. It will mean an increase in financial expenses and endangering their superior position in the world economy.

\section{Literature Review}

Carasco, et. al. (2013) show that in recent times, accumulation of foreign exchange reserves has been abetted by policymakers' desire to prevent currency appreciation, and to maintain the competitiveness of the tradable sector in countries. Ghosh, et. al. (2012) found that the reason for holding reserves varies according to the country's position in the global reserves distribution. Bacchetta, et al (2012) found that in a steady state it is optimal for the central bank to replicate the open economy, i.e. to issue debt financed by the accumulation of reserves so that the domestic interest rate equals the foreign rate. They also found that capital controls can still help reach the first best when the planner has more fiscal instruments. Dominguez, et. al (2012) focused not only on the total stock of official reserves held by countries, but also on the decisions by governments to purchase or sell reserve assets during the crisis period. Benigno and Fornaro (2012) found that by accumulating foreign reserves, the government induces a real exchange rate depreciation and a reallocation of production towards the tradable sector that boosts growth. Pina (2011) argued that accumulation of foreign exchange reserves can be explained by a simple model in which the central bank smooths inflation and stabilizes the exchange rate. Foreign exchange accumulation is the consequence of an increase in the incidence and magnitude of banking crises. Korinek and Serven (2010) showed that real exchange rate undervaluation through the accumulation of foreign reserves may improve welfare in economies with learning-by-investing externalities that arise disproportionately from the tradable sector. Olokoyo et al (2009) examines the case of Nigeria and found that there is a long-run linkage with foreign reserves and income, level of trade openness, foreign capital inflow and inflation. Obstfeld and Rogoff (2009) showed that the global imbalances of the 2000s and the recent global financial crisis are intimately connected. Neaime (2008) shows that after the shock of the exchange rate (exchange rate appreciation), price should be reduced. This is because in a small open economy, the prices of tradables adjust to world market prices. Interest rates are decreasing in response to the exchange rate appreciation, which indicates that the central bank is trying to alleviate the pressure of higher interest rates on GDP and stifled a further exchange rate appreciation. Aizenman (2007) points out that the rapid increase in foreign exchange reserves in emerging countries in recent years part of the complex changeable of global trends. The accumulation of foreign exchange reserves in recent times is caused by the accumulation competitive, the need for insurance against latent internal and external volatility and instability that is associated with increasing weakness of the balance sheet of the central bank. Wyplosz (2007) shows that the rapid accumulation of foreign exchange reserves when foreign exchange reserves are determined by GDP or exports. Aizenman \& Lee (2007) points out that the foreign exchange reserves can be considered as output stabilizers reduce the likelihood of falls in output caused by a sudden outflow of capital or the depth of the output collapse when it materializes sudden stop of capital inflows. Popov (2002) shows that intensive accumulation of foreign reserves has a stimulating effect on the long-term rate of economic growth in developing and emerging countries, though not in 
developed countries. The accumulation of foreign exchange reserves is an important macroeconomic mechanism for increasing the long-term rate of economic growth. Polterovich \& Popov (s.a.) show that it is possible to find an analogy between the accumulation of foreign exchange reserves and the Keynesian policy of fiscal expansion that runs the country out of recession. Kydland \& Prescott (s.a.) show that monetary policymakers with a clearly defined objective function, which depends on inflation and unemployment, controlling inflation through aggregate demand. The unemployment rate is a decreasing function of the sudden (unexpected) inflation. Polterovich \& Popov (s.a.) showed that the accumulation of foreign exchange reserves mitigates the effects of trade shocks on the real exchange rate. Volatility of terms of trade leads to volatility of the real exchange rate, which increases the volatility of the economic cycle. The countries accumulate foreign exchange reserves to stabilize the real exchange rate in the presence of volatile terms of trade shocks and volatile short-term capital flows. Excessive accumulation of foreign exchange reserves mitigates exposure to volatile terms of trade since the volatility of the real exchange rate reduces economic growth at a relatively low level of financial development.

\section{Empirical Analysis}

\subsection{Data Description}

In order to empirical estimates of the impact of foreign exchange reserves to economic growth in emerging countries, were collected annual data on real GDP per capita, share of investment in GDP and population from the database of the International Monetary Fund (IMF WEO) in October 2013, while data from the level of foreign exchange reserves statistics collected from the relevant central banks.

For a balanced panel data for Brazil, China and Russia, for the period from 1993 to 2012, estimated the relationship between economic growth and changes in foreign exchange reserves by applying the method includes the ONK with fixed individual effects. Definition of variables used in the model, the sources and the time period for which data are available are summarized in Table 1:

Table 1. Definition, Description of Variables, Data Sources, and the Time Period for Which Data are Available

\begin{tabular}{|c|c|c|c|}
\hline Variable & Description Variables & Source & Data Availability \\
\hline bdp & Real GDP per capita & IMF WEO, October 2013. & $\begin{array}{l}\text { Brazil: 1980-2012. } \\
\text { China: 1980-2012. } \\
\text { Russia: 1992-2012. }\end{array}$ \\
\hline fx_res & $\begin{array}{l}\text { The level of foreign } \\
\text { exchange reserves at } \\
\text { the end of the year }\end{array}$ & $\begin{array}{l}\text { Central Bank of Brazil, the } \\
\text { People's Bank of China and } \\
\text { the Central Bank of Russia }\end{array}$ & $\begin{array}{l}\text { Brazil: 1980-2012. } \\
\text { China: 1960-2012. } \\
\text { Russia: 1993-2012. }\end{array}$ \\
\hline inv_share & $\begin{array}{l}\text { The share of investment } \\
\text { in GDP }\end{array}$ & IMF WEO October 2013. & $\begin{array}{l}\text { Brazil: 1980-2012. } \\
\text { China: 1980-2012. } \\
\text { Russia: } 1990-2012 .\end{array}$ \\
\hline population & $\begin{array}{l}\text { Estimated population at } \\
\text { the end of the year }\end{array}$ & IMF WEO October 2013. & $\begin{array}{l}\text { Brazil: 1980-2012. } \\
\text { China: 1980-2012. } \\
\text { Russia: 1989-2012. }\end{array}$ \\
\hline
\end{tabular}

Table 2. given a summary of statistics for all variables used in the model for all three countries. Shows the average, minimum and maximum value for the period for which data are available.

\subsection{Methodology}

Given the fact that most macroeconomic variables unsteady, and the effect that neglect of these properties can have on the estimated coefficients were first conducted tests of unit root for each variable in level, as well as the differential of each of the first variable. The unit root in the panel is tested by applying Im, Peseran and Shin test, Levin, Lin and Chu test and Fisher test type. All tests test the null hypothesis of the existence of a unit root. Test results unit roots are summarized in Table 3:

Table 2. Summary Statistics for the Variables by Country

\begin{tabular}{|c|c|c|c|c|c|c|c|c|c|c|c|c|}
\hline \multirow[t]{2}{*}{ Country } & \multicolumn{3}{|c|}{$\begin{array}{l}\text { The growth rate of GDP } \\
\text { (in \%) }\end{array}$} & \multicolumn{3}{|c|}{$\begin{array}{l}\text { Foreign exchange reserves } \\
\text { (in millions of USD) }\end{array}$} & \multicolumn{3}{|c|}{$\begin{array}{l}\text { The share of investment in GDP } \\
\text { (in \%) }\end{array}$} & \multicolumn{3}{|c|}{$\begin{array}{l}\text { Population } \\
\text { (in millions) }\end{array}$} \\
\hline & average & $\min$ & $\max$ & average & $\min$ & $\max$ & average & $\min$ & $\max$ & average & $\min$ & $\max$ \\
\hline Brazil & 0,98 & $-6,62$ & 6,59 & 81835 & 3994 & 373147 & 18,25 & 14,34 & 22,51 & 163,03 & 120,81 & 198,36 \\
\hline China & 8,92 & 2,36 & 13,71 & 893477 & 20620 & 3333386 & 39,77 & 32,32 & 48,85 & 1208,03 & 1000,72 & 1354,04 \\
\hline Russia & 2,24 & $-12,76$ & 10,50 & 203043 & 6745 & 533218 & 22,81 & 14,83 & 30,02 & 145,24 & 141,44 & 148,5 \\
\hline
\end{tabular}


Table 3. The Test Results of Unit Root for GDP, the Level of Foreign Exchange Reserves, the Share of Investment in GDP and the Population in Level and First Difference

\begin{tabular}{|c|c|c|c|c|c|c|c|c|}
\hline & bdp & $\Delta$ bdp & fx_res & $\Delta$ fx_res & inv_share & $\Delta$ inv_shar & population $\triangle$ & $\Delta$ population \\
\hline Levin, Lin \& Chu t & $\begin{array}{c}4,35 \\
(1,00)\end{array}$ & $-1,48^{*}(0,06)$ & $\begin{array}{l}-0,25 \\
(0,40)\end{array}$ & $\begin{array}{c}-2,79 \\
(0,00)\end{array}$ & $\begin{array}{l}-0,10 \\
(0,46)\end{array}$ & $\begin{array}{c}-4,38 \\
(0,00)\end{array}$ & $\begin{array}{c}1,94 \\
(0,97)\end{array}$ & $3,43^{* * *}(0,00)$ \\
\hline Im, Pesaran \& Shin & $\begin{array}{c}4,09 \\
(1,00)\end{array}$ & $-2,52^{* *}(0,01)$ & $\begin{array}{c}0,03 \\
(0,53)\end{array}$ & $\begin{array}{l}-2,76^{* \pi *} \\
(0,00)\end{array}$ & $\begin{array}{l}-0,96 \\
(0,17)\end{array}$ & $\begin{array}{l}-7,42^{* * *} \\
(0,00)\end{array}$ & $0,33(0,63)$ & $-0,14(0,44)$ \\
\hline ADF-Fisher $\chi^{2}$ & $\begin{array}{c}0,17 \\
(0,99)\end{array}$ & $\begin{array}{c}18,52^{* *} \\
(0,01)\end{array}$ & $\begin{array}{l}10,15 \\
(0,12)\end{array}$ & $\begin{array}{l}18,08^{* *} \\
(0,01)\end{array}$ & $7,92(0,24)$ & $\begin{array}{c}54,29^{* * * *} \\
(0,00)\end{array}$ & $9,00(0,17)$ & $\begin{array}{c}24,05^{* \cdots * \pi} \\
(0,00)\end{array}$ \\
\hline $\begin{array}{c}\text { ADF- Choi Z } \\
\text { stat }\end{array}$ & $\begin{array}{c}3,95 \\
(1,00)\end{array}$ & $-2,25^{* * *}(0,01)$ & $\begin{array}{c}0,33 \\
(0,63)\end{array}$ & $\begin{array}{c}-2,83^{* \pi *} \\
(0,00)\end{array}$ & $\begin{array}{l}-0,73 \\
(0,23)\end{array}$ & $\begin{array}{l}-6,32^{* \pi * \pi} \\
(0,00)\end{array}$ & $0,45(0,67)$ & $\begin{array}{c}-3,37^{\pi * *} \\
(0,00)\end{array}$ \\
\hline PP-Fisher $\chi^{2}$ & $\begin{array}{c}0,65 \\
(0,00)\end{array}$ & $\begin{array}{l}18,06^{* *} \\
(0,01)\end{array}$ & $\begin{array}{c}0,91 \\
(0,99)\end{array}$ & $\begin{array}{l}12,07^{*} \\
(0,06)\end{array}$ & $7,61(0,27)$ & $\begin{array}{c}52,41^{* * * \pi} \\
(0,00)\end{array}$ & $\begin{array}{c}7,69 \\
(0,26)\end{array}$ & $\begin{array}{c}21,25^{* * \pi} \\
(0,00)\end{array}$ \\
\hline PP- Choi Z stat & $\begin{array}{c}2,17 \\
(0,98)\end{array}$ & $-2,12^{* *}(0,02)$ & $\begin{array}{c}2,94 \\
(1,00)\end{array}$ & $\begin{array}{l}-1,63^{*} \\
(0,05)\end{array}$ & $\begin{array}{l}-0,38 \\
(0,35)\end{array}$ & $\begin{array}{l}-6,14^{* * *} \\
(0,00)\end{array}$ & $3,4(0,99)$ & $\begin{array}{l}-3,15^{* * \pi} \\
(0,00)\end{array}$ \\
\hline
\end{tabular}

Note: p-values are in parentheses. *, ** and *** indicate levels of significance of $10 \%, 5 \%$ and $1 \%$, respectively.

Based on the results of tests of unit roots in panel, we conclude that for all variables in level can not reject the null hypothesis of non-stationarity, while the null hypothesis of non-stationarity can be rejected for the differential front of each of the variables, according to each of the tests, except for the first the differential variable population according to the results of the test Im, Peseran and Shina, which indicate the existence of a unit root in the first differential of these variables. Bearing in mind that all variables are non-stationary in levels, and that almost all of the tests indicate that the first difference of all the variables stationary panel estimated the model in which figuring as the first difference of variables.

The sample used in the empirical analysis is a balanced panel, the time period for which data are available for all three countries, ie the period from 1993 to 2012. In order to control the effects of those variables that are not explicitly included in the model are included and individual fixed effects $\beta_{0 i}$.

Taking into account the non-stationarity of variables in level and first difference stationarity, the two models are estimated using the OLS method on a sample of balanced panel. In both models, the first difference of the logarithm of GDP per capita (annual growth rate of real GDP) figuring as a dependent variable. In the basic model, the independent variables figuring first differential share of investment in GDP and the first difference of the foreign exchange reserves. In order to test the robustness of the results, a set of independent variables is extended with the inclusion of the first difference of the population.

In accordance with the theoretical positions, the expected positive correlation between foreign exchange reserves, the share of investment in GDP and economic growth. The basic model in which the growth rate of real GDP figuring as a dependent variable, while the independent variables occurring changes in foreign exchange reserves and changes in the share of investment in GDP is given by equation 1:

$$
\Delta \log (b d p)_{i t}=\beta_{0 i}+\beta_{1} \Delta \log \left(f x \_r e s\right)_{i t}+\beta_{2} \Delta \log (\text { inv_share })_{i t}+\varepsilon_{i t . .}
$$

In order to test the robustness of the obtained score, evaluated the new model, which in addition to changes in foreign exchange reserves and the share of investment in GDP includes first the differential variable population, and the annual change in population.

$$
\Delta \log (b d p)_{i t}=\beta_{0 i}+\beta_{1} \Delta \log \left(f x \_r e s\right)_{i t}+\beta_{2} \Delta \log (\text { inv_share })_{i t}+\beta_{3} \Delta \log (\text { population })_{i t}+\varepsilon_{i t} \ldots \ldots \ldots . . . . .
$$

The coefficients are estimated using the software package Eviews and their values are shown in Table 4:

Table 4. The Results of the Panel Regression for Brazil, China and Russia for the Period from 1993 to 2012.

\begin{tabular}{lcrrr}
\hline & \multicolumn{2}{c}{ Equations (1) } & \multicolumn{2}{c}{ Equations (2) } \\
\hline Variable & Coefficient & p-value & Coefficient & p-value \\
$\mathrm{C}$ & $0,03 * * *$ & 0,00 & $0,05^{* * *}$ & 0,00 \\
$\Delta \log ($ inv_share) & $0,17 * * *$ & 0,00 & $0,17 * * *$ & 0,00 \\
$\Delta \log ($ fx_res) & $0,06 * * *$ & 0,00 & $0,05 * * *$ & 0,00 \\
$\Delta \log$ (population) & & & $-0,29 * *$ & 0,05 \\
& $\mathrm{R}^{2}=0,68$ & $\mathrm{SC}=-3,99$ & $\mathrm{R}^{2}=0,70$ & $\mathrm{SC}=-3,97$ \\
& Adjusted $\mathrm{R}^{2}=0,66$ & $\mathrm{~F}-$ tatistics $=29,86$ & Adjusted $\mathrm{R}^{2}=0,67$ & $\mathrm{~F}$ - tatistics $=25,93$ \\
\hline
\end{tabular}


Note: $* * *$ and $* * *$ indicate statistical significance at the level of $10 \%, 5 \%$ and $1 \%$ respectively. The models include individual fixed effects.

Based on the coefficients shown in Table 4, it can be concluded that in the case of Brazil, China and Russia, the growth of foreign exchange reserves in the period from 1993 to 2012. the positive impact on economic growth. The estimated coefficients are robust to different model specifications.

The growth of the share of investment in GDP increases the growth rate of real GDP by 0.17 percentage points (the coefficient is statistically significant at a significance level of $1 \%$ in both specifications and has the same value).

Based on the results from Equations 1, we can conclude that the growth of foreign exchange reserves by one percentage point impact on the growth rate of GDP growth by 0.06 percentage points. The estimated coefficient is statistically highly significant (significance level of 1\%).

After the model was introduced variable that indicates population, the coefficient with changing foreign exchange reserves declined slightly (from 0.06 to 0.05 ) but was still statistically significant at a significance level of $1 \%$ (p-value $=0.00)$. Based on the results of two equations we can also conclude that in a given sample, the population growth of $1 \%$ leads to a decrease rate of GDP growth by 0.29 percentage points. This coefficient is significant at the level of significance of $5 \%$.

The introduction of the variable rate of population growth has improved the quality of the estimated model, the coefficient of determination is increased from $68 \%$ to $70 \%$. Also, the introduction of new variables influenced the growth of the corrected coefficient of determination, which has increased from $66 \%$ to $67 \%$ which indicates that the introduction of new variables in the model.

\subsubsection{Analysis of Causality}

In order to test in which the direction of causality between GDP and foreign exchange reserves, was conducted Granger causality test on the first series diference. Granger causality test is used to test the direction going causality between the two variables, in this case, whether the increase in foreign exchange reserves causes the growth of GDP or GDP growth causes the growth of foreign exchange reserves. Series that are determined Granger causality must be stationary, so that first used the observed difference series, ie changes in foreign exchange reserves and the growth rate of GDP.

First, we tested the hypothesis that the increase in foreign exchange reserves does not cause GDP growth. Estimated the following equation:

$$
\begin{aligned}
& \Delta \log (b d p)_{i t-1}=\beta_{0 i}+\beta_{1} \Delta \log (b d p)_{i t-1}+\beta_{2} \Delta \log (b d p)_{i t-2}+\ldots+\beta_{m} \Delta \log (b d p)_{i t-m}+\alpha_{1} \Delta \log \left(f x \_r e s\right)_{i t-1}+\alpha_{2} \Delta \log \left(f x \_r e s\right)_{i t-2} \\
& +\ldots+\alpha_{q} \Delta \log \left(f x_{-} \text {res }\right)_{i t-q} \varepsilon_{i t}
\end{aligned}
$$

The null hypothesis that $\Delta \mathrm{fx} \_$res not cause the growth rate of GDP implies that the coefficients $\alpha_{1,}, \alpha_{2, \ldots,}, \alpha_{q}=0$.

Number of lags is determined on the basis of the Schwarz criterion and is 4" in diameter.

The first row of Table 5. contains the result of Granger test for the first regression. Based on the p-value of 0.09 , we can conclude that the statistical significance of $10 \%$ reject the null hypothesis that the growth of foreign exchange reserves do not cause the growth of GDP, or accept the hypothesis that the increase in foreign exchange reserves affects the growth of GDP.

Causality in the opposite direction has been tested in the following manner: First, the estimated regression:

$$
\begin{aligned}
& \Delta \log \left(f x \_r e s\right)_{i t-1}=\beta_{0 i}+\beta_{1} \Delta \log \left(f x \_r e s\right)_{i t-1}+\beta_{2} \Delta \log \left(f x \_r e s\right)_{i t-2}+\ldots+\beta_{m} \Delta \log \left(f x \_r e s\right)_{i t-m}+\alpha_{1} \Delta \log (b d p)_{i t-1}+\alpha_{2} \Delta \log (b d p)_{i t-2} \\
& +\ldots+\alpha_{q} \Delta \log (b d p)_{i t-q} \varepsilon_{i t . .}
\end{aligned}
$$

The null hypothesis that $\Delta$ GDP not cause the growth of foreign exchange reserves implies that the coefficients in the second regression $\alpha_{1}, \alpha_{2}, \alpha_{q}=0$.

The result of Granger test for this equation is contained in the second row of Table 5. P-value of 0.13 indicates that the null hypothesis that GDP growth does not cause the growth of foreign exchange reserves can not be rejected. Granger causality test results are summarized in Table 5.

Table 5. Results Granger Causality Test

\begin{tabular}{ll}
\hline The null hypothesis & p-value \\
\hline$\Delta$ fx_res does not cause $\Delta$ gdp & $0,09^{*}$ \\
$\Delta$ gdp does not cause $\Delta$ fx_res & 0,13 \\
\hline
\end{tabular}

$*, * *$ and $* * *$ indicate levels of significance of $10 \%, 5 \%$ and $1 \%$, respectively.

Results in Table 5. suggest that the increase in foreign exchange reserves causes the growth of GDP, while in the 
opposite direction causality has not been proven.

\section{Conclusion}

Arguments for the accumulation of foreign exchange reserves are different. However, the most important argument is that the accumulation of foreign reserves leads to undervalued exchange rate, which stimulates the export sector. There are positive effects of the unbalanced (undervalued) real exchange rate. The accumulation of foreign exchange reserves in emerging countries is correlated with a higher rate of economic growth. The accumulation of foreign exchange reserves is rapid when the foreign currency reserves determined by GDP or exports. When you have determined the financial variables (credit, money supply), the situation is completely different. The larger the stock of foreign exchange reserves to emerging countries greater credibility, the stability of their positions abroad, reducing the risk of speculative attacks, repayment of foreign debt and reduce financial costs. The accumulation of foreign exchange reserves has not only reinforced the ratio of investment / GDP, but the share of exports and trade in GDP. The ratio of trade / GDP is positively correlated with the accumulation of foreign exchange reserves, and negatively correlated with the ratio in domestic prices / foreign prices.

Intense accumulation of foreign exchange reserves has a stimulating effect on the long-term rate of economic growth in developing countries and emerging countries, though not in the developed countries. The accumulation of foreign exchange reserves is an important macroeconomic mechanism for increasing long-term economic growth rates. Leads to the depreciation of the exchange rate, increase in revenues and profits of the export sector, increasing investment and economic growth based on higher exports. It also leads to an increase in prices of tradable goods and profits, because profits and non-tradable prices lag behind the increase in prices of tradable goods. Foreign exchange reserves can be considered a stabilizer output because they reduce the likelihood of falling output caused by a sudden outflow of capital or the depth of the collapse of output when it materializes sudden stop of capital inflows. However, in developed countries, excessive stock of foreign exchange reserves is unwarranted if they can borrow in the international financial capital market, when necessary.

Undervalued exchange rate is a common feature of most emerging economies as it should achieve a trade surplus to fund the repayment of foreign debt and sudden capital outflows. Many emerging economies implemented a deliberate policy undervalued exchange rate as part of the overall export strategy. Preventing the appreciation of the exchange rate through the accumulation of foreign exchange reserves, they are able to restrain spending and imports and stimulate exports, investment and economic growth. The continuous appreciation of the real exchange rate will sooner or later result in the foreign exchange crisis.

Emerging economies tend to have depressed the exchange rate, ceteris paribus, which means a lower ratio of domestic prices / foreign prices, which is achieved by the rapid accumulation of foreign exchange reserves. As a result, there is a positive correlation between the accumulation of foreign exchange reserves, the share of investment in GDP and economic growth. In developing countries and emerging countries overvalued exchange rate is detrimental to economic growth. Countries that have accumulated large stock of foreign exchange reserves had higher rates of economic growth. For example, the country with the fastest economic growth in the world over the period 1960-2000. is Botswana, which has increased its GDP per capita of more than ten times (6\% average annual growth in GDP per capita over the period of 40 years). Also, Botswana is a country with the highest ratio in foreign exchange reserves / GDP.

High economic growth is usually in conjunction with a higher ratio in trade / GDP, and thus higher ratio in foreign exchange reserves / GDP. One of the ways to achieve the optimal level of international trade and realize revenues from trade externalities is the accumulation of foreign exchange reserves, which would lead to exchange rate depreciation and higher exports. Countries with large stock foreign exchange reserves have depressed real exchange rate, which leads to an increase in the share of exports in GDP.

If the accumulation of foreign reserves leads to the depreciation of the exchange rate and results in a higher relative price of tradables (relative to earnings and non-tradable prices) and higher profit, founded expected to result in greater savings ratio in the investment / GDP. However, on the other hand, does not generate any depreciation of the exchange rate more investment, but only the depreciation caused by an active policy of accumulation of foreign exchange reserves. If the exchange rate is depressed due to capital outflows, it would only cause the transformation of limited domestic savings into capital outflows, all at the expense of investment. Therefore, the relationship between investment and foreign exchange reserves is stronger than the link between investment and exchange rate depreciation. The relationship between the accumulation of foreign exchange reserves and the share of investment in GDP is quite strong.

The increase in investment is linked to foreign trade. In other words, an increase in investment and output is associated with the growth of exports and output in the tradables sector. This is the main advantage of the accumulation of foreign exchange reserves as it provides not only a rapid increase in investment, but also a high return on investment and high capital productivity due to greater involvement in international trade. The ratio of foreign trade / GDP depends on the 
level of development (GDP per capita) and the size of the economy (smaller economies are more involved in international trade and the share of trade in GDP grows faster). The ratio of foreign trade / GDP is correlated with an increase in foreign exchange reserves, depreciation of the exchange rate (the ratio of domestic prices / foreign prices) and a lower level of non-tradable prices to the prices of tradable goods.

One might think that the accumulation of foreign reserves leads to inflation. However, this is not the case, if the rate of accumulation of foreign exchange reserves does not exceed the rate of economic growth. Slightly higher inflation is not necessarily harmful, particularly for developing countries and emerging economies. The accumulation of foreign exchange reserves is not inflationary and influence increase economic growth and employment, in contrast to the rapid depreciation of the exchange rate that occurs as a result of maintaining an overvalued exchange rate in the long run, which leads to foreign exchange crisis and inflation. It is difficult to advocate the idea that successful economic growth leads to a rapid accumulation of foreign exchange reserves since the accumulation of foreign exchange reserves is one of the variables of economic growth. If successful economic growth accompanied by a rapid accumulation of foreign exchange reserves, the question is whether the accumulation of foreign exchange reserves necessary prerequisite for economic growth. The empirical results in this paper suggest that the increase in foreign exchange reserves causes the growth of GDP, while in the opposite direction causality has not been proven.

\section{References}

Aizenman, J., Yothin, J., \& Park, D. (2011). International reserves and swap lines: Substitutes or complements? International Review of Economics \& Finance, 20(1). http://dx.doi.org/10.1016/j.iref.2010.07.002

Aizenman, J. (2007). Large Hoarding of International Reserves and the Emerging Global Economic Architecture. USCS and the NBER. http://dx.doi.org/10.3386/w13277

Alberola, E., \& Serena, J. M. (2007). Global Financial Integration, Monetary Policy and Reserve Accumulation. Assessing the Limits in Emerging Economies. Banco de Espana, Documento de Trabajo.

Barbosa-Filho, N. H. (2008). Inflation Targeting and Monetary Policy in Brazil. International Review of Applied Economics.

Benigno, J., \& Fornaro, L. (2012). Reserve accumulation, growth and financial crises. CEPR Discussion Papers, Centre for Economic Performance, LSE.

Bianchi, J., Hatchondo, J. C., \& Martinez, L. (2013). International Reserves and Rollover Risk. IMF Working Paper, 33. http://dx.doi.org/10.5089/9781475571295.001

Chami, S., McGettigan, D., \& Watt, S. (2007). Jordan's International Reserve Position: Justifiably Strong, IMF Working Paper, Washington: International Monetary Fund.

Chang, R. (2007). Inflation Targeting, Reserves Accumulation and Exchange Rate Management in Latin America. Department of Economics, Rutgers University, New Brunswick.

Cheng, G. (2013). A Growth Perspective of Foreign Reserve Accumulation, Banque de France, Working Paper, 443.

Dominguez, K. M. E., Yuko, H., \& Takatoshi, I. (2012). International Reserves and the Global Financial Crisis, NBER Working Papers.

Durdu, B., Mendoza, E., \& Terrones, M. (2007). Precautionary Demand for Foreign Assets in Foreign Stop Economies: An Assessment of the New Mercantilism, mimeo.

Elhiraika, A., \& Ndikumana, L. (2007). Reserves Accumulations in African Countries: Sources, Motivations and Effects.

Emmanuel, U. C. (2013). Foreign Exchange Reserves (Fer) Accumulation And Macro-Economic Stability: The Nigerian Experience. International Journal of Business and Management Invention.

Fukuda, S., \& Kon, Y. (2010). Macroeconomic Impacts of Foreign Exchange Reserve Accumulation: Theory and International Evidence. ADBI Working Paper, Tokyo: Asian Development Bank Institute.

Ghosh, R., Ostry, J., \& Tsangarides, C. (2012). Shifting motives: Explaining the buildup in official reserves in emerging markets since the 1980s, IMF Working Papers, IMF. http://dx.doi.org/10.5089/9781463933197.001

Goldberg, L., Hull, C. E., \& Stein, S. (2013). Do Industrialized Countries Hold the Right Foreign Exchange Reserves? Federal Reserve Bank of New York.

Green, R., \& Torgerson, T. (2007). Are High Foreign Exchange Reserves in Emerging Markets a Blessing or a Burden? Office of International Affairs Occasional Paper, 6.

Gupta, A. S. (2008). The Cost of Holding Excess Reserves: Evidence from India. Prepared for Presentation at the 
Brookings-NCAER India Policy Forum, New Delhi.

Jeanne, O., \& Ranciere, R. (2011). The optimal level of international reserves for emerging market countries: A new formula and some applications, Economic Journal, 121(555). http://dx.doi.org/10.1111/j.1468-0297.2011.02435.x

Krušković, B. (2014). Monetary strategies, exchange rate and foreign exchange reserves, Economics Faculty, University of Banja Luka.

Obstfeld, M., Jay, S. C., \& Taylor, A. M. (2010). Financial Stability, the Trilemma and International Reserves. American Economic Journal: Macroeconomics, 2(2).

Olayungbo, D. O., \& Akinbobola, T. O. (2011). Foreign Exchange Reserves and Exchange Rates in Nigeria. Structural Breaks, Unit Roots and Cointegration tests. Journal of Social and Economic Development.

Osorio, P. C. (2007). The Motivation and Methodology for Breaking Foreign Reserves in Tranches. Central Bank of Colombia.

Pina, G. (2011). The Recent Growth of International Reserves in Developing Economies: A Monetary Perspective, Universitat Pompeu Fabra.

Polterovich, V., \& Popov, V. (2007). Economic Growth, Real Exchange Rate and Inflation. New Economic School.

Polterovich, V., \& Popov, V. (2002). Accumulation of Foreign Exchange Reserves and Long Term Growth, NES Working Paper.

Sell, F. L. (2007). Anticipated Effects of Foreign Currency Reserve Diversification in Asian Countries: Do Chima and India Matter for Coordination? CESifo Forum.

Sosunov, K., \& Zamulin, O. (2006). The Inflationary Consequences of Real Exchange Rate Taregting via Accumulation of Reserves. Centre for Economic and Financial Research at New Economic School, Working paper, 82.

Steiner, A. (2010). Central Banks' Dilemma: Reserves Accumulation, Inflation and Financial Instability. Grade School of Economic, A Social Sciences, University of Mannheim, Germany.

Truman, E. M. (2007). The Management of China's International Reserves: China and a SWF Scoreboard. Peterson Institute for International Economics.

Usman, A., \& Waheed, I. (2010). External Reserves Holding in Nigeria: Implications for Investment Inflation and Exchange Rate, Journal of Economics and International finance, 2(9).

Wen, Yi. (2011). Making sense of China's excessive foreign reserves. Working Paper Series, Federal Reserve Bank of St. Louis

Wyplosz, C. (2007). The Foreign Exchange Reserves Buildup: Business as Usual? Graduate Institute of International Studies and CEPR.

\section{(cc) $\mathrm{BY}$}

This work is licensed under a Creative Commons Attribution 3.0 License. 